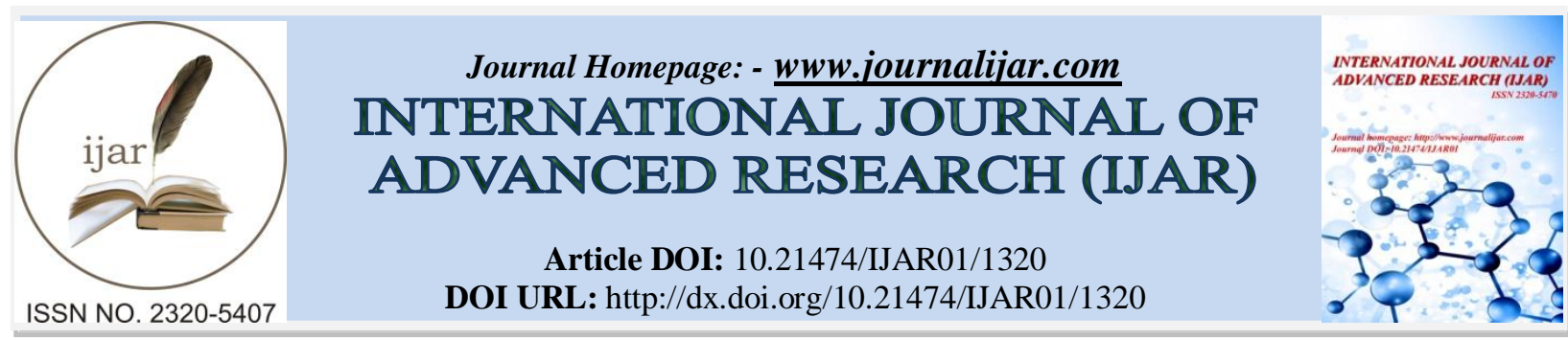

RESEARCH ARTICLE

\title{
THE LISTENING ABILITY IN ENGLISH OF THE LEARNERS JOINING SECONDARY SCHOOL IN KENYA: A CASE STUDY OF THE MUTONGUNI SECONDARY SCHOOL IN KITUI COUNTY.
}

\author{
Dr. Lydiah W. Wangungu and Dr. Paul N. Mwangi. \\ South Eastern Kenya University.
}

\section{Manuscript Info}

Manuscript History

Received: 16 June 2016

Final Accepted: 17 July 2016

Published: August 2016

Key words:-

\section{Abstract}

The Kenyan government through various polices has emphasised the teaching of English in all primary schools in Kenya. It is thus expected that when learners are exiting primary schools and entering secondary schools, they have acquired the Desired Competence Levels in listening in English. The present study was conducted with the aim of establishing the levels of competence in listening in English of the learners joining secondary schools in Kenya.

Gender is a significant factor in the education system given the social and cultural role that education plays in the society. The study investigated the influence of gender on these competence levels. Purposive sampling was used to select a sample of 20 girls and 20 boys from the Mutonguni Secondary School in Kitui County. A test comprising dictation, cloze test and listening comprehension components was administered to the respondents.

ANOVA was conducted to establish whether the different performances in the different listening tasks between the genders were statistically significant or not. The findings were that gender as a social variable only influenced performance in the listening comprehension but not performance in the cloze test and dictation.

Pearson correlation test was used to correlate the different performances in the different listening tasks. Performance in the listening comprehension correlated with performance in dictation while performance in the cloze test did not correlate with performance in any other listening task.

Copy Right, IJAR, 2016,. All rights reserved.

\section{Introduction:-}

Listening Competence in English:-

Effective listening is a process that involves actively absorbing the information given by a speaker, showing that you are attentive and providing feedback to the speaker so that he/she knows that the message has been received. Effective listeners show speakers that they have been heard and understood by responding effectively (Baker, 1971).

There is a difference between listening and hearing. Whereas hearing is a physical activity, listening is a mental process (Adler \& Brown, 2003). We do not learn how to hear but we must learn how to listen. As expressed by Wyatt and Roach (1999) "far from being a natural process, listening is a consciously purposive activity for which we 
need systematic training and supervision to learn to do well" (p. 197). Byrne (1984) says listening involves psychological skills such as recognising words, parsing speech into constituent parts and processing the discourse in terms of cohesion, logic and relevant underlying skills as well as social skills such as giving back-channelling signals and making improvements when misunderstandings occur.

Groenwegen (2008) records a study by Kenyatta University staff that came up with English Literacy Norms (ELNs ). These are the bench marks or levels of competence in language skills that are expected in a learner at finishing primary school. ELNs defined the Desired Competence Level (DCL) as a score of $75 \%$ and above in a language skill task. The Minimum Competence Level (MCL) was defined as a score between $50 \%$ and $74 \%$ in a language skill task. With the MCL, learners have limited ability in the language skill and therefore are not able to use the skill effectively. With DCL, learners have the ability to use the language skill effectively.

Listening has been assuming greater and greater importance in language classrooms because of development of second language acquisition research which has emphasised the role of comprehensible input (Krashen, 1982). Krashen (1982) argues that the teacher provides the learner with the comprehensible input which the learner interacts with and takes it in for learning to take place. In order to interact with the comprehensible input, the learner must have the desired levels in listening skill. This is especially so in the Kenyan context where teacher talk comprises $75 \%$ of the classroom interaction (Gathumbi, 1995).

The revised K.C.S.E syllabus has re-emphasised the importance of listening skills by incorporating listening skills in the teaching and evaluation syllabus in national examinations. It is on this emphasis on the role of listening skills in the learning process that this study was pegged with a view to establishing whether learners joining secondary school in Kenya have the desired levels of competence in listening skills in English. The influence of the social variable of gender on the listening ability of learners joining secondary school in Kenya was also established by the study.

Listening is the first language skill that a child acquires. "It produces a foundation for all aspects of language and cognitive development and plays a lifelong role in the process of learning and communication essential to productive participation in life" (Hyslop \&Bruce, 1988: 1).

Studies have shown that infants begin to respond to a new word by hearing and listening. Wilding (2001) illustrated how neonates were able to discriminate between their fathers' voice and that of a male stranger. He showed how babies rapidly developed the ability to combine visual and auditory stimuli at the age of six to twelve weeks. They became distressed when shown a video of their mother in which the speech and visual content were discrepant (Wilding, 2000).

During the period of rapid language growth, listening contributes enormously to the child's acquisition of speech (Hyslop \& Bruce, 1988). It can therefore be termed as a pre-requisite skill on which all other interactive skills are predicated. As aptly expressed by "if you are not an effective listener, you are going to have consistent trouble developing other interpersonal skills" (Robbins \& Hunsaker 1996, 35). Listening skill is therefore at the heart of communicative development since a child has to learn to listen before learning to speak, speak before learning to read and read before learning to write.

According to Littlewood (1981) most learners will spend considerably more time listening to language than the time they will spend producing it themselves. It is not only that they must understand what is said to them during face-toface interaction; it is also that they will come across a vast range of situations where they will be silent receivers of messages directed to them from radio, television announcements and a multitude of other sources.

Byrne (1986) argues that learners' ability to understand (comprehend what they listen to) needs to be considerably more than their ability to speak if they are to be "comfortable" in a foreign or second language classroom and therefore be able to communicate effectively.

When speaking, it is the learners who select the language that is used. To some extent, therefore, they can compensate for deficiencies in their repertoire, through communicative strategies such as using paraphrases or simplifying messages. When listening, however, they do not normally have any control over the language that is used. They must be prepared to extract meaning as best as they can from whatever language that is directed at them. 
It is therefore not enough that they should merely be able to understand the same range of language that they can speak. Their receptive repertoire must be matched not against their own productive repertoire but against the productive repertoire of the speakers they will need to understand. In addition, they must be prepared to cope with a wide range of situational and performance factors which are outside their control.

In Kenya, English is the language of education and the civil service (Mbaabu, 1996). Moreover, it is the language of both intra and inter-ethnic communication. English is also used as the language of the media, parliament, legal system, judiciary, publications, military and diplomacy (Njoroge, 2006).

Learners therefore need the ability to listen attentively and the ability to respond in English in the classroom and during day-to-day interactions. When learners lack listening and speaking skills in English, they shy away from the needful participation in class and out-of-class activities. Therefore, the main objective for teaching English should be the 'acquisition of communicative competence and not simply on the passing of examinations......becoming proficient in the language is a lifelong goal (K.I.E 2002, English Syllabus: 2).

The current language policy in Kenya states that English is to be taught as a compulsory subject from standard one to form four and is to be used as a medium of instruction from standard four upwards. The language of instruction from standard one to three is the mother tongue or the language of the catchment area (Njoroge, 2006).

The revised K.C.S.E syllabus re-emphasises the importance of English as the official language of communication in Kenya as well as the medium of instruction in schools, colleges and universities. It is also the pre-eminent language of interactional communication. It states that 'those who master English reap many academic, social and professional benefits' (Revised Integrated English syllabus 2002: v). To enable learners to reap these benefits, their listening skills need to be ascertained.

Listening involves skills such as recognising words, parsing speech into constituent parts and processing the discourse in terms of cohesion, logic and back channelling signals. Listening competences include discriminating between sounds, recognising words, identifying stressed words, identifying functions in a conversation, connecting linguistic cues to non- linguistic cues in order to construct meaning, recalling important words, topics and ideas, giving appropriate feedback to the speaker and reformulating what the speaker has said. In this paper the researchers focused on discriminating between sounds through dictation, recalling important words through cloze test and connecting linguistic and non-linguistic cues to construct meaning as well as using background knowledge and context to predict and confirm meaning in the listening comprehension.

The above survey on listening skills shows that listening is vital in language learning. It also shows that listening helps in acquisition of the other language skills. It is also evident that learners depend heavily on listening in the learning classes. The importance of English is also highlighted in the survey. It is for these reasons that this study sought to establish the listening competence levels in English of learners joining secondary schools in Kenya and the influence of gender on these listening competence levels. The central thesis is that, given the government's strong emphasis on the teaching of English in primary schools in Kenya, the listening competences in English language are at the Desired Competence Level for a majority of learners joining secondary schools in Kenya.

\section{Methodology and Materials:-}

This study sought to establish the listening competence levels in English of learners joining secondary school in Kenya. The study further sought to establish the influence of the social variable of gender on these listening competence levels. In order to do so, the study was conducted as a case study in which Mutonguni Secondary School in Kitui County was sampled through purposive sampling. The school was ideal as it is a mixed county school hence controlling for the needed variable of gender.

Mutonguni Secondary School is a three-streamed mixed school with two boys' classes and one girls' class. Through simple random sampling, ten boys from class A, ten from class B and twenty girls from the girls' class were selected. The study sample was therefore comprised of forty form-one students who had just joined secondary school.

In carrying out the study, the researcher administered three listening tasks: A listening comprehension, a cloze test and a dictation. Listening comprehension is viewed theoretically as an active process in which individuals focus on 
selected aspects of aural input, construct meaning from passages and relate what they hear to existing knowledge. The data elicited from the listening comprehension was in the form of sentences. The respondents listened to a comprehension passage which was read to them twice by the researcher and from which oral questions were drawn (appendix). The respondents here used their listening skills as well as their schemata to answer the questions.

In the cloze test, the respondents had to listen for specific words. A passage was read to the respondents and later on, the same passage was re-read but with some words left out. The respondents were expected to write down the missing words using listening skills such as inferences and memorisation.

Using dictation, the researcher collected data in the form of sounds. This was as a result of the respondents being given minimal pairs to fill in slots in sentences. The focus here was on the sounds /f/ and $/ \mathrm{v} /$ as well as sounds /p/ and /b/ in minimal pairs such as" fan and van" and "push and bush ". This was done because the geographical area in which the research was carried out has a population that has problems differentiating the said sounds and this may interfere with their listening skills.

ANOVA test was conducted to establish whether the differences in performances in the different listening tasks by the two genders were by chance or they were statistically significant. Pearson's' correlation test was conducted to correlate the performances in the different listening tasks.

\section{Key Findings:-}

After administering the three sub-tests, the subtests were marked and the raw scores turned into percentages. To establish the listening ability in English of each respondent, the mean score of the three sub-tests was calculated for each respondent. To establish the influence of gender on the learners' listening ability in English, the mean scores were calculated for both the sub-groups of male respondents and that of female respondents and analysed. The results are shown in the Table 1, Table 2 and Table 3. The tables contain percentages only because the number of observations in the form of absolute figures was low, for example, the comprehension test comprised only four questions and was marked out of 10 marks.

Table 1: Scores by the male respondents on the three sub-tests

\begin{tabular}{|c|c|c|c|c|}
\hline Respondent & COMPREHENSION (\%) & CLOZE $(\%)$ & DICTATION (\%) & OVERALL (\%) \\
\hline M1 & 40 & 90 & 80 & 70 \\
\hline M2 & 100 & 20 & 80 & 67 \\
\hline M3 & 80 & 70 & 60 & 70 \\
\hline M4 & 70 & 30 & 80 & 60 \\
\hline M5 & 80 & 30 & 50 & 53 \\
\hline M6 & 90 & 60 & 70 & 73 \\
\hline M7 & 80 & 60 & 70 & 70 \\
\hline M8 & 80 & 50 & 60 & 63 \\
\hline M9 & 30 & 60 & 60 & 50 \\
\hline M10 & 20 & 50 & 60 & 73 \\
\hline M11 & 80 & 60 & 70 & 40 \\
\hline M12 & 30 & 60 & 40 & 77 \\
\hline M13 & 100 & 50 & 70 & 73 \\
\hline M14 & 80 & 60 & 80 & 70 \\
\hline M15 & 80 & 60 & 70 & 50 \\
\hline M16 & 70 & 80 & 20 & 87 \\
\hline M17 & 90 & 40 & 90 & 57 \\
\hline M18 & 60 & 40 & 70 & 80 \\
\hline M19 & 80 & 50 & 60 & \\
\hline M20 & 100 & & 90 & \\
\hline
\end{tabular}


Table 2:- Scores by the female respondents on the three sub-tests.

\begin{tabular}{|l|l|l|l|l|}
\hline Respondent & COMPREHENSION (\%) & CLOZE (\%) & DICTATION (\%) & OVERALL (\%) \\
\hline F1 & 70 & 50 & 70 & 63 \\
\hline F2 & 90 & 30 & 60 & 60 \\
\hline F3 & 80 & 60 & 70 & 70 \\
\hline F4 & 100 & 60 & 70 & 77 \\
\hline F5 & 80 & 60 & 80 & 73 \\
\hline F6 & 90 & 30 & 50 & 57 \\
\hline F7 & 90 & 40 & 70 & 67 \\
\hline F8 & 80 & 50 & 60 & 63 \\
\hline F9 & 80 & 40 & 80 & 67 \\
\hline F10 & 80 & 70 & 80 & 77 \\
\hline F11 & 80 & 60 & 50 & 63 \\
\hline F12 & 60 & 80 & 50 & 63 \\
\hline F13 & 80 & 60 & 80 & 73 \\
\hline F14 & 80 & 70 & 30 & 60 \\
\hline F15 & 100 & 60 & 60 & 73 \\
\hline F16 & 100 & 70 & 30 & 67 \\
\hline F17 & 90 & 50 & 70 & 70 \\
\hline F18 & 80 & 70 & 90 & 80 \\
\hline F19 & 80 & 60 & 50 & 63 \\
\hline F20 & 90 & 60 & 70 & 73 \\
\hline
\end{tabular}

Table 3:- Means of male respondents and female respondents on the three sub-tests and overall test.

\begin{tabular}{|l|l|l|l|}
\hline Sub-test & $\begin{array}{l}\text { MEAN PERCENTAGE } \\
\text { FOR THE MALE } \\
\text { RESPONDENTS }\end{array}$ & $\begin{array}{l}\text { MEAN PERCENTAGE } \\
\text { FER THE FEMALE } \\
\text { RESPNDENTS }\end{array}$ & $\begin{array}{l}\text { MERCENTAGE FOR } \\
\text { THE ENTIRE } \\
\text { SAMPLE }\end{array}$ \\
\hline COMPREHENSION (A) & 72 & 84 & 78 \\
\hline CLOZE(B) & 54 & 57 & 56 \\
\hline DICTATION(C) & 67 & 64 & 66 \\
\hline OVERALL & 64 & 68 & 67 \\
\hline
\end{tabular}

From the findings in the Table 3, female respondents performed better than male respondents in the listening comprehension and in the cloze test. However, male respondents performed better than female respondents in the dictation.

One- way ANOVA was computed for the purpose of testing the significance of the differences in the two sub groups (male and female) or the sample means in the different subtests. This helped to determine whether the differences in the means in the subtests were significant or the differences were by chance. The findings are indicated in Table 4.

Table 4:- ANOVA.

\begin{tabular}{|l|l|l|l|l|l|l|}
\hline \multicolumn{2}{|c|}{} & Sum of Squares & df & Mean Square & F & Sig. \\
\hline \multirow{2}{*}{$\begin{array}{l}\text { Listening scores } \\
\text { comprehension }\end{array}$} & Between Groups & 1440.000 & 1 & 1440.000 & 4.275 & .046 \\
\cline { 2 - 7 } & Within Groups & 12800.000 & 38 & 336.842 & & \\
\cline { 2 - 7 } & Total & 14240.000 & 39 & & & \\
\hline \multirow{5}{*}{ Cloze test scores } & Between Groups & 90.000 & 1 & 90.000 & .393 & .535 \\
\cline { 2 - 7 } & Within Groups & 8710.000 & 38 & 229.211 & & \\
\hline & Total & 8800.000 & 39 & & & \\
\hline \multirow{3}{*}{ Dictation scores } & Between Groups & 90.000 & 1 & 90.000 & .332 & .568 \\
\cline { 2 - 7 } & Within Groups & 10310.000 & 38 & 271.316 & & \\
\cline { 2 - 7 } & Total & 10400.000 & 39 & & & \\
\hline
\end{tabular}


The findings in Table 4 show that the performance of learners joining secondary schools in Kenya in the listening comprehension was significant at 0.046. This implies that gender influenced the performance of males and females joining secondary schools in Kenya in the listening comprehension. The significance level in performance of the cloze test was at 0.535 . This is way above 0.05 and we therefore conclude that the performance of males and females joining secondary schools in Kenya in the cloze test was not influenced by gender but rather the difference was by chance. The findings also suggest that the difference in performance of males and females joining secondary schools in Kenya in the dictation was also by chance. It was not influenced by the social variable of gender as the significance level was at 0.568 which is above 0.05 .

In an attempt to establish the relationship among performances in the different listening tasks, Pearson's correlation coefficient was computed. The findings are contained in Table 5.

Table 5:- Correlation of performance in different listening subtests..

\begin{tabular}{|c|c|c|c|c|}
\hline & & $\begin{array}{l}\text { Comprehension } \\
\text { scores }\end{array}$ & $\begin{array}{l}\text { Cloze } \\
\text { scores }\end{array}$ & $\begin{array}{l}\text { Dictation } \\
\text { scores }\end{array}$ \\
\hline \multirow{3}{*}{$\begin{array}{l}\text { Listening } \\
\text { scores }\end{array}$} & Pearson Correlation & 1 & -.143 & .173 \\
\hline & Sig. (2-tailed) & & .379 & .287 \\
\hline & $\mathrm{N}$ & 40 & 40 & 40 \\
\hline \multirow[t]{3}{*}{ Cloze test scores } & Pearson Correlation & -.143 & 1 & -.021 \\
\hline & Sig. (2-tailed) & .379 & & .898 \\
\hline & $\mathrm{N}$ & 40 & 40 & 40 \\
\hline \multirow[t]{3}{*}{ Dictation scores } & Pearson Correlation & .173 & -.021 & 1 \\
\hline & Sig. (2-tailed) & .287 & .898 & \\
\hline & $\mathrm{N}$ & 40 & 40 & 40 \\
\hline
\end{tabular}

The findings indicate that when performance in the listening comprehension was correlated with performance in the cloze test, the two performances recorded a negative correlation with a Pearson's correlation coefficient of -0.143. Performances in the listening comprehension and in the dictation on the other hand recorded a minimal correlation with Pearson's correlation coefficient of 0.173 . Performance in the cloze test was correlated with performances in the listening comprehension and in the dictation. The results show that they recorded negative correlations with Pearson's correlation coefficients of -0.143 and -0.021 respectively. Performance in dictation had a slight correlation with performance in the listening comprehension but had no correlation with performance in the cloze test. We therefore conclude that performance in the listening comprehension and performance in the dictation had a slight correlation but there was no correlation between performance in the cloze test and performances in the listening comprehension and in the dictation.

\section{Discussion:-}

The respondents did best in the listening comprehension test (subtest A). They attained a mean score of $78 \%$ which is above the Desired Competence Level. This was mainly attributed to the task being popularly taught and tested in other subjects. In teaching a subject like history, learners listen to the teacher and then respond to his or her questions.

The second best performed subtest was dictation (subtest C). Though the majority of the respondents did not attain the Desired Competence Level, the sample population managed a mean score of $66 \%$ which though below the Desired Competence Level is above the Minimum Competence Level.

Respondents performed poorly in the cloze test (subtest B). The task demanded that respondents organise their thoughts to be able to fill given slots correctly and also use sequential ordering as well as relate one idea to another. The respondents attained a mean score of $56 \%$ which is slightly above the Minimum Competence Level but below the Desired Competence Level.

From the findings in Table 3, it is evident that overall, girls performed better than boys by scoring a mean percentage mark of 68 against 64. However, in the different sub-tests, the performance varied. In the listening comprehension, both male and female respondents performed well but the girls performed better than the boys by scoring a mean of $84 \%$ against $72 \%$. The good performance by the two sub groups was seen as a result of the 
listening comprehension being a skill that almost all teachers of all the subjects engage in, in evaluating their learners understanding at the end of the lesson.

In the cloze test, the two groups performed dismally. The overall mean for the respondents was $56 \%$. The girls however performed slightly better than the boys with means of 57\% and 54\% respectively. Although the average mark of the sample population was slightly above the Minimum Competence Level, only $8 \%$ of the sample population attained the Desired Competence Level according to the English Literacy Norms (ELNs) which put the Desired Competence Level at $74 \%$ and above. In performing this sub-test, the learners needed high-order listening sub-skills such as organisation of thoughts, sequential ordering and relating one idea to another. More so, the subtest was in the form of a narration unlike sub-test $\mathrm{A}$ which was in the form of a dialogue. The better performance in the dialogue than in the narration may be attributed to the fact that we listen more to dialogue than narration in dayto-day life.

In the dictation, the performance of the whole group was fairly good as the overall mean was $66 \%$. The boys however performed slightly better than the girls with means of $67 \%$ and $64 \%$ respectively. This performance was fairly above the Minimum Competence Level. The fair performance was attributed to the fact that learners usually listen to and take dictation in many subjects. Any subject can be used by the teacher to dictate information, facts, direction and instructions. Test questions can also be dictated in class.

Results from ANOVA test showed that the different performances in the different listening subtests noted between male and female learners were by chance except in the listening comprehension. This implies that gender influenced performance in the listening comprehension but did not influence performance in the cloze test and in the dictation. Pearson's correlation test showed that performances in the listening comprehension and performance in the dictation correlated slightly but performance in the cloze test did not correlate with performance in any other listening subtest.

\section{Recommendations for Pedagogy:-}

The research showed that learners performed best in the listening comprehension which was in form of a dialogue. The instructors should therefore get their listening materials from resources that are ideal to the daily interactions of the learners. The study also noted that listening comprehension and dictation which had fairly good performance were practised by almost all instructors in all the subjects. This implies that practice would go a long way in enhancing listening skills of learners.

Cloze test recorded a poor performance than the other listening tasks. In view of this, instructors should expose learners to listening sub skills needed in performing cloze test such as sequential ordering and relating one idea to another as learners seem not to have acquired these sub skills.

Girls generally performed better than boys. The instructors should use these findings to encourage male learners to improve their listening skills. ANOVA results indicated that gender influenced performance in the listening comprehension and not performance in the cloze test and dictation. There is need therefore for instructors to use varied materials for listening comprehension that are gender sensitive.

Pearson's correlation coefficient indicated that performance in the listening comprehension correlated with performance in dictation. The listening sub skills needed to perform the listening comprehension are related to the sub skills needed to perform dictation and the instructors should therefore teach the subs kills together as they are dependent on each other.

\section{Conclusion:-}

This was a case study that sought to establish the levels of listening competences in English of learners joining secondary schools in Kenya. The influence of gender on these listening competence levels was also sought. To establish the listening competences, a listening test comprising a listening comprehension, a cloze test and a dictation was administered. The test was marked and a percentage mark awarded to each respondent in each listening subtest and in the listening test. The percentage mark was used to establish whether respondents had the Desired Competence Level or the Minimum Competence Level in the different subtests of the listening test. The mean scores of all male respondents versus that of all female respondents in the different subtests were calculated in an attempt to establish the influence of gender on these listening competences in the different listening subtests and 
in the listening test. ANOVA was used to establish whether the different performances in the subtests and in the listening test by the genders were by chance or were statistically significant. Pearson's correlation test correlated the different performances in the different subtests.

All the respondents managed to reach the minimum level of competence in all the sub-tests. The respondents performed quite well in the listening comprehension managing a mean score of $78 \%$, a score that is above the Desired Competence Level. The listening comprehension was in the form of a dialogue. This implies that learners need to listen to ideal spoken language which has all the characteristics of natural language use. They should also listen to what is common in day-to-day interactions to ease their listening process.

In subtest $\mathrm{C}$ which was in form of dictation, respondents attained the MCL but failed to attain the DCL. Their mean score in subtest $\mathrm{C}$ was $66 \%$. The good performance may be attributed to practice since majority of instructors dictate notes and questions to learners. In subtest B, the respondents attained a mean score of 56\% and so failed to attain the DCL but attained the MCL. There is therefore need to expose learners to the listening sub skills that require learners to organise their thoughts, use sequential ordering as well as relate one idea to another as they seem not to have acquired these skills effectively as reflected by the poor performance in the cloze test.

Stevick (1980) and Sharwood-Smith (1981) claim that 'learnt' or explicit knowledge can turn into 'acquired' or implicit knowledge if there is enough practice. The skill therefore becomes over-learnt and completely automatic. The findings of this study corroborate this view. The listening comprehension and dictation were performed better than the other cloze test. This is because the procedure used in evaluating listening comprehension is commonly employed in evaluation in all the other subjects and dictation is used to dictate notes and questions in almost all the classes. The practice in the two subtests has therefore become over - learnt and completely automatic. Learners should therefore be exposed to listening skills associated with cloze test in order to enhance their listening ability.

Gender as a social variable influenced performance in the listening comprehension as indicated by the ANOVA test. However, it did not influence performance in the cloze test and in dictation. This should help in material development for listening classes where materials for listening comprehension should be based on the different genders unlike materials for cloze test and dictation. Since performance in the listening comprehension and in the dictation correlated, we conclude that listening sub skills needed in performance of the two listening subtests build on each other and therefore the instructors should teach the sub skills together as they enhance each other.

\section{References:-}

1. Adler, R. And B. Rodman. 2003. Understanding Human Communication. New York: Oxford

2. University Press.

3. Allan, W. 2013."Managing innovation in English language education: A research agenda".Language Testing, 47/01: 92-110.

4. Baker, L. 1971. Listening Behaviour. London: Prentice Hall, Inc.

5. Byrne, D. 1986. Testing Oral English. London: Longman.

6. Byrne, H.1984.The role of listeningcomprehension: A theoretical base. Foreign language annals 17:317-329

7. Bwire, A. 2007. Learner competencies and proficiency in English Listening Comprehension in selected schools in Kenya. Unpublished $\mathrm{PhD}$ Thesis, Kenyatta University.

8. Dunamis, N. And R. Tennyson. 2012. "Listening skill requires a further look into second/foreign language learning". Hossein Bozorgian. 1/1: 34-39

9. Gathumbi, A.1995. Verbal discourse events in a bilingual formal setting: Instructional Procedures in ESL classrooms in Kenya secondary schools. Unpublished PhD thesis, University of Reading, UK.

10. Groenwegen, T. 2008 Benchmarks for English Language Education. Nairobi: Phoenix Publishers Limited.

11. Hyslop, N. And T. Bruce.1988. "Listening: Are we teaching it, and if so How?" Eric Digest No. 3: 35-37

12. Kenya Institute of Education 2002. Revised English Syllabus for Kenya Primary Schools Nairobi: Kenya Literature Bureau.

13. Kenyatta University 2004. English Literacy Norms Project. Nairobi: Kenyatta University.

14. Krashen, S. 1982. The study of Second Language Acquisition. Oxford: Oxford University Press.

15. Littlewood, W. 1981. Communicative Language Teaching. Cambridge: Cambridge University Press.

16. Mbaabu, I. 1996. Language Policy in East Africa: A Dependency Theory Perspective. Nairobi: Educational Research and Publications. 
17. Moulic, M. 2012. "Developing Effective Listening Skills to Enhance Professional Efficiency". ELT Journal, 3/1: 25.

18. Nesi, H.2013. "Dictionary use by English Language Learners.” Language Testing, 47/1: 38-55

19. Nesi, H. 2013." The role and importance of lower level processes in second language reading. Language Testing. 47/1: 1-37.

20. Njoroge, M. 2006. Linguistic variation in spoken English as used by teachers in Kenyan primary schools. Unpublished PhD Thesis, Kenyatta University.

21. Sharwood-Smith, M. 1981. Consciousness-Raising and the Second Language Acquisition Oxford: Blackwell Publishers.

22. Shellenbarger, S. 2014. "Tuning in: Improving your listening skills". Journal of Property Management, 63/4: 111-113.

23. Stevick, L. 1980. Explorations in Applied Linguistics. London: Heinemann.

24. Tenderoni, J. 2000. Hemisphere dominance and language proficiency levels in the four macro-skills of the Western Mindanao State University

25. College students. Unpublished doctoral dissertation, University of Mindanao, Philippines.

26. Vandergrift, L. 2004. "Listening to learners learn to listen" Annual Review of Applied Linguistics, 24/3: 25.

27. Vandergrift, L. and J. Cross. 2014. "Guideline for designing and conducting second language listening studies". ELT Journal, 65/3: 318-321.

28. Walker, R. 2014. "Teaching and learning second language listening:

29. Metacognition in action". ELT Journal, 68/2: 211-213.

30. Wilding, S. 2000. Cognitive and Brain science. New York: NOVA Science publishers, Inc.

31. Wilkinson, A. 1974. Language and Education. London: Oxford University Press.

32. Wyatt, D. and S. Roach. 1999. "Computer assisted teaching and testing of reading and listening." Foreign Language Annals, 17/4: 393-407.

33. Xuesong, G., L. Yanyi and L. Yuxia. 2011. "Empirical studies on foreign language Learning and teaching in China”. Language Teaching, 47/1: 56-79.

34. Yalcinkaya, F., B. Muluk and S. Sahin.2009. "Effects of listening ability on speaking, writing and reading skills of children who were suspected of auditory

35. processing difficulty”. International Journal of Pediatric Otorhinolaryngology, 73/8: 1137-1142.

36. Zhang, J. and A. Wu.2009. "Chinese senior high EFL students' metacognitive awareness and reading strategy use." Reading in a Foreign Language, 21/1:37-59.

37. Zoltan, D. 2011. "Researching complex dynamic systems: Retrodictive qualitative modeling in the language classroom". Language Teaching. 47/1: 80-91.

Appendix: The listening tests.

The Listening comprehension test:-

Listen carefully to the following dialogue and answer the questions that follow IT.

I want to tell you, er, about some friends of mine, um, the Jones family, that's Jim and, el, Ann Jones. Now they, they live in a flat, on the third floor. Well, you know, I think they're crazy. I don't know why they live in a third floor flat because it's very, very noisy and its right in the el, in the centre of London. It's really rather silly, because, well, they've got three children, there's David, he's ten; John, he's eight and Sue, she's only two. And well, David's got two dogs and Sue's got a kitten.

(Adapted from Practical Techniques in Language Teaching, pg. 68) QUESTIONS BY LYDIAH WANGUNGU Questions:-

1. Where does Jones' family live?

(1 mark)

2. What kind of a home do they have?

$(1$ mark)

3. Give the names of their children and their ages. (6 marks)

4. What pets do their children keep?

(2 marks)

The cloze Test:-

Listen carefully to this passage. It will be read twice. On the first reading, no word will be omitted but on the second reading, some words will be omitted. Supply the missing words to complete the passage. 
When I saw my friend last night, she gave me a present. I first met Anne at a workshop in Nanyuki and we have been great friends since then. Anne used to work in Nyeri but she left last year. She acts very maturely. I really approve of that type of behaviour. I also like her sense of humour. Her daughter is equally humorous. What a great family she has!

The Dictation test:-

Listen to the following sentences carefully and choose one of the words read to you twice by the researcher to fill in each gap.

1. The boy cut a --------- in the garden (vine, fine).

2. He bought a ----------- of wheat flour (pail, bale)

3. The child was accused of---------- sickness (feigning, veining)

4. The thieves hid in the-------- (push, bush).

5. The lost child was found by the -------- bearers (pall, ball).

6. The ------ are ploughing (bulls, pulls).

7. They boarded the -------- (very, ferry).

8. He threw the dirt in the (pit, bit).

9. In my------- the students are to blame (few, view)

10. Football -------- were excited (vans, fans). 